\title{
Medical Management of Dysfunctional Menorrhagia: Is Ormeloxifene a Safe and Efficacious Therapeutic Choice?
}

\author{
Nidhi Gupta
}

\section{ABSTRACT}

Objective: To assess the efficacy and safety of ormeloxifene (centchroman) in the medical management of menorrhagia.

Materials and methods: One hundred and twenty women with menorrhagia were recruited for the study. One hundred women were analyzed. Ormeloxifene was given to each patient$60 \mathrm{mg}$ twice a week for 3 months and then once a week for 1 month. Patients were followed up at 2, 4, 6 months of therapy, then at 6 months after treatment was stopped. Menstrual blood loss (MBL) was measured objectively by a pictorial blood loss assessment chart (PBAC) score and subjectively by a visual analog scale (VAS).

Results: The mean age of the patients was 38.2 years with a mean parity of 2.4. The mean duration of menorrhagia was 13 months with 8 days as mean duration of bleeding and a mean cycle length of 26 days. $58.7 \%$ of the patients had bulky uterus on per vaginum examination done by the same observer. The mean endometrial thickness on transvaginal scan was $8.7 \mathrm{~mm}$. The different study parameters were evaluated in patients treated with ormeloxifene and it showed a significant reduction in median PBAC score from 252 to 102.8, presence of clots from 64 to $12 \%$, incidence of dysmenorrhea from 22 to $8 \%$ and mean endometrial thickness from 9.7 to $6.7 \mathrm{~mm}$. There was also a significant elevation in the mean hemoglobin levels from $8.85 \mathrm{gm} / \mathrm{dl}$ to $10.6 \mathrm{gm} / \mathrm{dl}$.

The menstrual pattern of patients treated with ormeloxifene were encouraging. Eight percent of the women became ammenorhoeic after 6 months of therapy, $22 \%$ had scanty period, $56 \%$ had average flow, $12 \%$ had heavy from and only $2 \%$ had very heavy flow.

It was further seen, that even though the PBAC score increased to 112.7 after stopping treatment for 6 months, but still it was lower than the pretreatment level (252). The percentage of patients who had an initial history of passage of clots during periods decreased from 64 to $12 \%$ and also $22 \%$ of patients who complained of mild to severe dysmenorrhea improved and only $8 \%$ of the patients complained of mild dysmenorrhea.

Adverse effects: Included ovarian cyst (14\%), cervical erosion and discharge $(11 \%)$, gastric upset $(9 \%)$, headache $(5 \%)$ and weight gain $(3 \%)$.

Conclusion: Ormeloxifene is an effective and safe therapeutic option for the medical management of menorrhagia.

\section{Associate Professor}

Department of Obstetrics and Gynecology, SN Medical College Agra, Uttar Pradesh, India

Corresponding Author: Nidhi Gupta, Associate Professor Department of Obstetrics and Gynecology, SN Medical College Agra, Uttar Pradesh, India, e-mail: dr.nidhi_gupta@rediffmail.com

\author{
Keywords: Centchroman, Menorrhagia, Ormeloxifene.
}

How to cite this article: Gupta N. Medical Management of Dysfunctional Menorrhagia: Is Ormeloxifene a Safe and Efficacious Therapeutic Choice? J South Asian Feder Menopause Soc 2014;2(2):65-70.

\section{Source of support: Nil}

Conflict of interest: None

\section{INTRODUCTION}

Menorrhagia is a common cause of disability affecting about 10 to $33 \%$ of women at some stage in their lives. ${ }^{1}$ In majority of cases, no organic disease can be attributed to this condition and then it is termed as dysfunctional or essential menorrhagia.

Menorrhagia is usually defined as menstrual blood loss of at least $80 \mathrm{ml}$ or more per cycle ${ }^{2}$ and on a pictorial blood loss assessment chart (PBAC) score of more than $100 .^{3}$

Though, the definitive treatment of dysfunctional menorrhagia is hysterectomy, but this involves hospitalization, anesthesia, morbidity, loss of fertility and it may not be the preferred choice in all women. Dysfunctional menorrhagia is usually seen in premenopausal women in whom the condition usually rectifies with the onset of menopause. ${ }^{4}$

Although, endometrial ablative procedures, an alternative to hysterectomy, may show promising results but their use is limited especially in low resource settings like ours. The cost, a long learning curve, high recurrence rates and the absence of cost-effective, easy and universal availability of the first and second generation procedures limits their use. ${ }^{5}$

Drug therapy should therefore, be the first line of treatment in all cases of dysfunctional menorrhagia before recourse to surgery. ${ }^{6}$ Although, a large number of drugs 7,8 have shown promising results but still it is seen that many women remain menorrhagic despite a $50 \%$ decrease in mean blood loss by agents like tranexamic acid, mefenamic acid, flurbiprofen, norethisterone and ethamsylate. Secondly, there is paucity of recommendations to guide its systematic implementation and lastly long-term daily oral drug treatment has restricted usage due to poor compliance and unacceptable side effects. Though, the use of the Levonorgestrel intrauterine system 
(LNG-IUS) ${ }^{9}$ is showing promising results in menorrhagia, the usage is limited in low resource settings due to its limited availability, skill in application and cost.

Selective estrogen receptor modulators (SERMs) represent a novel therapeutic drug class in the medical management of menorrhagia. Their actions are dichotomously defined at the molecular level; pharmacologic actions are composite of estrogen agonistic and antagonistic effects. The cardinal features of SERMs that are useful is their high affinity to bind to nuclear estrogen receptors, causing antagonistic estrogen effects in the uterus and breast tissue and estrogen mimicking actions on the skeletal, cardiovascular and central nervous systems. ${ }^{10}$

Ormeloxifene is a nonsteroidal SERM developed as centchroman by Indian Central Drug Research Institute, Lucknow, India ${ }^{11}$ and used as a weekly oral contraceptive for around 20 years. During this usage, it was observed in India that this drug has a beneficial effect on dysfunctional uterine bleeding and endometriosis. This led to controlled trials of this drug for this indication. It is also undergoing clinical evaluation for treatment of breast diseases (mastalgia, fibroadenoma, breast carcinoma) and prevention of osteoporosis due to its potent antiestrogenic, weak estrogenic ${ }^{12,13}$ and antiprogestational activities. $^{14}$

\section{MATERIALS AND METHODS}

After ethical approval was obtained, the study was conducted at the department of Obstetrics and Gynecology, Malhotra Nursing Home and Rainbow Hospital, Pvt Ltd, Agra, India and the effect of Ormeloxifene was studied in cases of dysfunctional menorrhagia.

Two hundred patients with menorrhagia (between January 2010 and January 2014 ) were randomly selected from the outdoor department of the obstetrics and gynecology of the above hospitals for the study. Fifty were excluded as they failed to fulfill the inclusion criteria and 50 were lost to follow-up and 100 were analyzed. They were clinically evaluated with a detailed menstrual history pertaining to cycle length and duration of bleeding. PBAC score and visual analog scale (VAS) was used for assessment of passage of clots and dysmenorrhea.

Patients, whose menstrual blood loss on the PBAC scored more than 100 were recruited.

Hemograms were performed as well as ultrasonography was done to rule out pelvic pathology and to measure the endometrial thickness.

Endometrial biopsy was done for all patients.

Exclusion criteria included presence of any pelvic or systemic pathology (e.g. platelet disorder, coagulopathies, previous $\mathrm{h} / \mathrm{o}$ thrombosis, renal or hepatic dysfunction), pregnancy, associated infertility and endometrial hyper- plasia with atypia. Endocrinopathy or other systemic diseases causing menorrhagia were also excluded from the study.

The women were preferably multipara, who did not wish to conceive within the study period and had no clinical evidence of jaundice or hepatic dysfunction, polycystic ovarian disease, cervical hyperplasia, chronic cervicitis and hypersensitivity to the drug.

Informed written consent was taken from all the patients.

Two pretreatment menstrual cycles were studied and then compared to six consecutive treatment cycles with ormeloxifene. The drug was administered orally in the form of a tablet $60 \mathrm{mg}$ twice a week for the first 12 weeks and then once a week for another 12 weeks.

Follow-ups were done at 2, 4, 6 months of therapy to asses improvement of symptoms. After the therapy was stopped, each patient was followed-up for a period of 6 months. Thus, the total duration of the study was 12 months.

The main outcome measures were menstrual blood loss, blood hemoglobin levels and endometrial thickness in the proliferative phase as studied by transvaginal sonography (TVS).

The patients were asked to keep records of their menstrual patterns, bleeding days and amount of menstrual blood loss. They were also advised to bring the empty packets of drugs used by them. Follow-up was done at 2, 4 and 6 months of therapy and then 6 months after stopping the therapy. At each visit, cycle length, duration of bleeding, PBAC score any side effect and patients subjective account of bleeding and dysmenorrhea was assessed by VAS.

Amenorrhea was defined as absence of menstruation for two consecutive cycles. Patients with a PBAC score of $\leq 10$ was defined as scant flow; between 10 and 100 as moderate flow; $>100$ as heavy flow and $>300$ as very heavy flow.

No hormone, antifibrinolytics or any other agent to control menorrhagia was prescribed during the study.

A repeat endometrial biopsy was performed in all patients if on TVS endometrial thickness was $>10 \mathrm{~mm}$.

If menorrhagia was controlled over 4 cycles of treatment, the treatment was considered a success. Women who developed the same symptoms of dysfunctional menorrhagia in the follow-up period and who requested repeat treatment with ormeloxifene were recorded as represcription cases and started treatment.

Pictorial blood loss assessment chart (PBAC), a method that correlates well, with the alkaline test method ${ }^{15}$ was used to measure the menstrual blood loss. A well designed questionnaire recorded the subjective assessment of 
menstrual flow and dysmenorrhea and any side effects of the drug. Menstrual flow was designated as light, normal or average, heavy and flooding. Number and size of clots passed were also noted. Dysmenorrhea was categorized as absent, mild, moderate and severe.

\section{RESULTS}

A total of 200 women (Flow Chart 1) with menorrhagia (PBAC Score $>100$ ) were screened and out of which 50 cases were excluded due to presence of systemic or pathological disease (Flow Chart 1).

One hundred and fifty were enrolled for the study and informed consent was taken but 30 women were lost to follow-up and only 120 women were analyzed and started therapy.

Out of the 120 women only 110 women continued therapy after the 1st follow-up (2 months after therapy) and 4 of these had poor response and opted for other forms of medical therapy, 4 underwent hysterectomy and 2 were lost to follow-up.

In the next follow-up after 4 months, two women opted out of the study due to poor response and underwent hysterectomy. Only 100 patients reported for the 3rd follow, after 6 months of therapy six patients were lost to follow-up and two showed poor response with therapy.

The number of patients reporting 3 and 6 months after stopping therapy were 98 and 96 respectively (two in each group were lost to follow-up). Ours is a tertiary teaching hospital catering to a wide population from the neighboring districts and the patients who were lost to follow-up were mainly the rural dwellers in the low socioeconomic group, who did not report even on contacting and counseling them telephonically.

Table 1 delineates the patient characteristics treated with ormeloxifene. The mean age of the patients was

Flow Chart 1: A disposition tree showing the number of patients screened, enrolled, analyzed and lost the follow-up in the study of ormeloxifene in management of menorrhagia

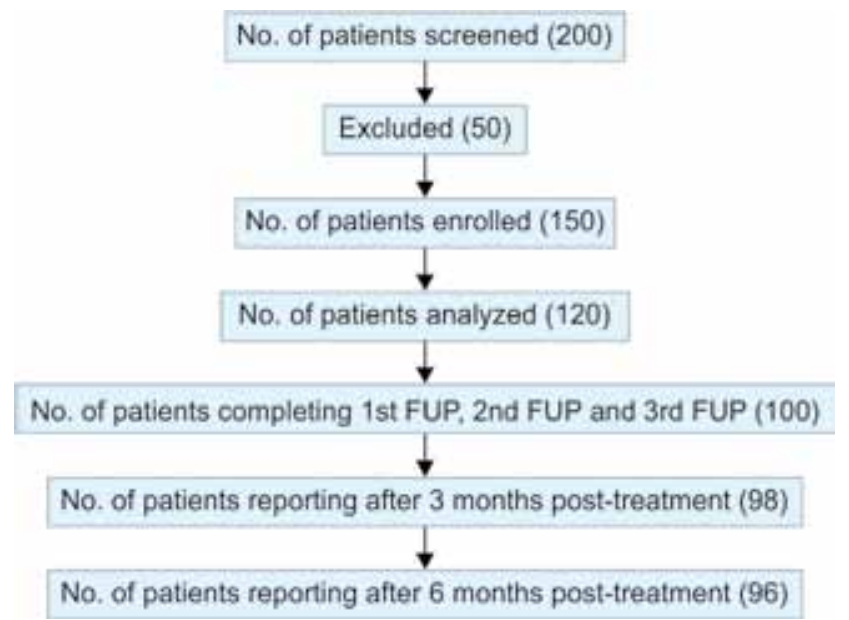

38.2 years with a mean parity of 2.4. The mean duration of menorrhagia was 13 months with 8 days as mean duration of bleeding and a mean cycle length of 26 days. $58.7 \%$ of the patients had bulky uterus on per vaginum examination done by the same observer. The mean endometrial thickness on transvaginal scan was $8.7 \mathrm{~mm}$. An endometrial aspiration was done in all patients and endometrium was sent for histopathological evaluation (Table 2). The endometrium was secretory in 52\%, proliferative in $33.4 \%$, simple hyperplasia without atypia in $9.8 \%$, cystic hyperplasia without atypia in $3.6 \%$ and with atypia in $1.2 \%$ (Table 2). The patient with endometrial hyperplasia with atypia was referred for hysterectomy.

As regards the adverse effects (Table 3) of the drug, $58 \%$ reported no side-effects, in fact eight patients who had mastalgia benefited from the treatment. $11.8 \%$ of cases complained of severe abdominal pain and on ultasonography had ovarian cyst which were simple follicular in type with a mean diameter of $6.7 \mathrm{~cm}$. Most of the cysts were simple follicular and benign which disappeared within 3 months of stopping therapy (one of the patient showed a complex cyst with a diameter of $9.8 \mathrm{~cm}$ but, later it was confirmed to be a hemorrhagic cyst).

Table 1: Patient characteristics

\begin{tabular}{llll}
\hline S no. & Patient characteristics & Mean score & Range \\
\hline 1 & Age & 38.2 years & $27-51$ years \\
2 & Parity & 2.4 & $0-5$ \\
3 & $\begin{array}{l}\text { Duration of } \\
\text { menorrhagia }\end{array}$ & 13 months & $4-56$ months \\
4 & $\begin{array}{l}\text { Duration of } \\
\text { bleeding days }\end{array}$ & 8 days & $4-30$ days \\
5 & $\begin{array}{l}\text { Cycle length } \\
6\end{array}$ & $\begin{array}{l}\text { Size of uterus on P/N } \\
\text { examination done by } \\
\text { same observer. }\end{array}$ & $16-30$ days \\
& $\begin{array}{l}\text { - Normal size } \\
\text { - Bulky uterus }\end{array}$ & $58.7 \%$ & \\
& Endometrial thickness \\
by TVS & 8.7 mm & $5-15$ mm \\
\hline
\end{tabular}

Table 2: Histopathological evaluation of endometrial thickness of all patients enrolled in the study

\begin{tabular}{|c|c|c|c|}
\hline $\begin{array}{l}S \\
\text { no. }\end{array}$ & $\begin{array}{l}\text { Histopathological } \\
\text { evaluation of endometrial } \\
\text { aspiration }\end{array}$ & $\begin{array}{l}\text { Number } \\
\text { (out of 150) }\end{array}$ & Percentage \\
\hline 1 & Secretory endometrium & $78 / 150$ & 52.0 \\
\hline 2 & Proliferative endometrium & $50 / 150$ & 33.4 \\
\hline 3 & $\begin{array}{l}\text { Simple hyperplasia } \\
\text { without atypia }\end{array}$ & $14 / 150$ & 9.8 \\
\hline 4 & $\begin{array}{l}\text { Cystic hyperplasia } \\
\text { without atypia }\end{array}$ & $06 / 150$ & 3.8 \\
\hline 5 & $\begin{array}{l}\text { Cystic hyperplasia } \\
\text { with atypia }\end{array}$ & $02 / 150$ & 1.2 \\
\hline
\end{tabular}


Out of $9.2 \%$ of the patients in the study reported vaginal discharge which was excessive and per speculum examination of these cases revealed that they had cervical erosion. All these patients underwent a Pap smear and a colposcopic directed biopsy whenever it was required. Gastric upset in the form of nausea, bloating and belching was seen in $7.1 \%$ cases and $6.2 \%$ of the cases reported vague and nonspecific low abdominal pain and these were relieved by medication and change of diet. $4.8 \%$ of cases reported headache and $2.9 \%$ reported weight gain (2.5 kg in 12 months).

The different study parameters were evaluated in patients treated with ormeloxifene (Table 4) and it showed a significant reduction in median PBAC score from 252 to 102.8 , presence of clots from 64 to $12 \%$, incidence of dysmenorrhea from 22 to $8 \%$ and mean endometrial thickness from 9.7 to $6.7 \mathrm{~mm}$. There was also a significant elevation in the mean hemoglobin levels from 8.85 to $10.6 \mathrm{gm} / \mathrm{dl}$.

The menstrual pattern of patients (Table 5)treated with ormeloxifene were encouraging. $8 \%$ of the women became amenorrhoeic after 6 months of therapy, $22 \%$ had scanty period, $56 \%$ had average flow, $12 \%$ had heavy from and only $2 \%$ had very heavy flow.

Out of $8 \%$ of patients with amenorrhea only two cases continued to be amenorrhoeic even after stopping therapy (4th follow-up) and the rest resumed their menses within 3 to 6 months of stopping therapy. These patients were in the 48 to 51 years age group and the amenorrhea was welcomed by them.

Table 3: Adverse effects seen with ormeloxifene reported by the patients

\begin{tabular}{llll}
\hline $\begin{array}{l}S \\
\text { no. }\end{array}$ & Side-effect & $\begin{array}{l}\text { Number } \\
\text { (Out of 100) }\end{array}$ & Percentage \\
\hline 1 & No side-effects reported & $58 / 100$ & 58 \\
2 & $\begin{array}{l}\text { Severe abdominal pain } \\
\text { (ovarian cyst on USG) }\end{array}$ & $14 / 100$ & 14 \\
3 & $\begin{array}{l}\text { Discharge (cervical } \\
\text { erosion on p/s }\end{array}$ & $11 / 100$ & 11 \\
& examination) & & \\
4 & Gastric upset & $09 / 100$ & 9 \\
5 & Headache & $05 / 100$ & 5 \\
6 & Weight gain & $03 / 100$ & 3 \\
\hline
\end{tabular}

Table 5: Menstrual pattern of patients during treatment with ormeloxifene

\begin{tabular}{llll}
\hline $\begin{array}{l}S \\
\text { no. }\end{array}$ & Menstrual pattern & $\begin{array}{l}\text { Pretreatment } \\
\text { (\%) }\end{array}$ & $\begin{array}{l}\text { Post-treatment } \\
\text { (6 months) (\%) }\end{array}$ \\
\hline 1 & Amenorrhea & 0 & 8 \\
2 & Scanty & 0 & 22 \\
3 & Average & 24 & 56 \\
4 & Heavy & 65 & 12 \\
5 & Very heavy & 11 & 2 \\
\hline
\end{tabular}

It was observed that, 12 patients had recurrence of symptoms after 6 months of stopping the therapy. Suprisingly, ${ }^{8}$ patients opted for the same medical treatment, that is ormeloxifene and 2 each opted for other forms of medical management and hysterectomy.

It was seen, that even though the PBAC score increased to 112.7 after stopping treatment for 6 months, but still it was lower than the pretreatment level (252). The percentage of patients who had an initial history of passage of clots during periods decreased from 64 to $12 \%$ and also $22 \%$ of patients who complained of mild to severe dysmenorrhea improved and only $8 \%$ of the patients complained of mild dysmenorrhea.

\section{DISCUSSION}

Medical management for dysfunctional menorrhagia should aim to relieve symptoms of menorrhagia, improve the quality of life and avoid risk of hysterectomy. It should be safe, easy to administer with minimal side effects and the therapeutic advantage should also continue even after stopping the therapy. Till date, no such drug has been marketed and the drugs available seems to provide only partial relief from menorrhagia. ${ }^{16}$

Ormeloxifene, a new drug, added to this medical armamentarium has a long lasting estrogen antagonistic action and lately studies are showing it to be a safe and effective therapeutic option in the management of dysfunctional uterine bleeding. Secondly, due to a long half life elimination ${ }^{17}$ doses provide for easy and convenient biweekly and then after building adequate and effective blood levels of the drug shifting to weekly doses. Thirdly, its effect is local, with no effect on the hypothalmopituitary axis, so it does not affect ovulation. It causes an increase in cycle length by lengthening the follicular phase.

Table 4: Evaluation of outcome in patients treated with ormeloxifene

\begin{tabular}{lllll}
\hline $\begin{array}{l}S \\
n o .\end{array}$ & Parameter & Pretreatment & $\begin{array}{l}\text { Post-treatment } \\
\text { (6 months) }\end{array}$ & Significance \\
\hline 1 & Median PBAC score & $252(144-785)$ & $102.8(58.6-388)$ & $\mathrm{p}<0.001$ \\
2 & Mean hemogram level $(\mathrm{gm} / \mathrm{dl})$ & $8.85(6.5-10.8)$ & $10.6(9.8-12.8)$ & $\mathrm{p}<0.001$ \\
3 & Mean endometrial thickness $(\mathrm{mm})$ & $8.7(5-15 \mathrm{~mm})$ & $6.7(3-10)$ & $\mathrm{p}<0.001$ \\
4 & $\begin{array}{l}\text { Presence of clots } \\
\text { (proportion of patients) }\end{array}$ & $64 \%$ & $12 \%$ & \\
5 & $\begin{array}{l}\text { Dysmenorrhea } \\
\text { (proportion of patients) }\end{array}$ & $22 \%$ & $8 \%$ & \\
\hline
\end{tabular}




\begin{tabular}{|c|c|c|c|c|c|c|c|c|c|}
\hline \multirow[t]{2}{*}{ S no. } & \multirow[t]{2}{*}{ Parameter } & \multicolumn{2}{|c|}{ Chandra et al 2004} & \multicolumn{2}{|c|}{ Kriplani et al 2009} & \multicolumn{2}{|c|}{ Tapan et al 2010} & \multicolumn{2}{|c|}{ Present study } \\
\hline & & $\begin{array}{l}\text { Pre- } \\
\text { treatment }\end{array}$ & $\begin{array}{l}\text { Post- } \\
\text { treatment }\end{array}$ & $\begin{array}{l}\text { Pre- } \\
\text { treatment }\end{array}$ & $\begin{array}{l}\text { Post- } \\
\text { treatment }\end{array}$ & $\begin{array}{l}\text { Pre- } \\
\text { treatment }\end{array}$ & $\begin{array}{l}\text { Post- } \\
\text { treatment }\end{array}$ & $\begin{array}{l}\text { Pre- } \\
\text { treatment }\end{array}$ & $\begin{array}{l}\text { Post- } \\
\text { treatment }\end{array}$ \\
\hline 1 & $\begin{array}{l}\text { Median PBAC } \\
\text { score }\end{array}$ & 272 & 107.8 & 388 & 96 & 108.7 & 62.48 & 252 & 102.8 \\
\hline 2 & $\begin{array}{l}\text { Mean hemoglobin } \\
\text { level }(\mathrm{gm} / \mathrm{dl})\end{array}$ & 9.42 & 10.73 & 10.6 & 11.2 & 8.49 & 11.028 & 8.85 & 10.6 \\
\hline 3 & $\begin{array}{l}\text { Mean endometrial } \\
\text { thickness }(\mathrm{mm})\end{array}$ & 11.4 & 7.8 & 10.9 & 7.3 & 11.5 & 8 & 8.7 & 6.7 \\
\hline 4 & $\begin{array}{l}\text { Presence of } \\
\text { clots }(\%)\end{array}$ & 74.1 & 12.9 & 64.3 & 7.1 & 80 & 8 & 64 & 12 \\
\hline 5 & $\begin{array}{l}\text { Presence of } \\
\text { dysmenorrhea (\%) }\end{array}$ & 27.05 & 5.88 & 71.4 & 25 & - & - & 22 & 8 \\
\hline
\end{tabular}

The mean blood loss decreased significantly in our study which is in concordance with other studies with medical management ${ }^{18}$ though less than with the LNGIUS system ${ }^{19}$ (Table 6). It was further observed that $8 \%$ of women became amenorrhoeic with $22 \%$ of women having scanty menses and $56 \%$ of women had a average menstrual blood flow. So, it was observed that in $86 \%$ of women menorrhagia was cured. Similar results were such by the study conducted by Kriplani et al, ${ }^{20}$ in whom menorrhagia was cured in $78 \%$ of patients, $46 \%$ patients had amenorrhea and $32 \%$ had regular scant to moderate menstrual blood loss. Similar, results were seen by study conducted by Chandra et $\mathrm{al}^{21}$ where there was an improvement of menorrhagia in $85.7 \%$ of cases and amenorrhea was observed in $17.64 \%$ of the cases. Similar results were also shown by the study conducted by Tapan et al. ${ }^{22}$

Ormeloxifene has got a good safety profile with very few side effects. In our study, none of the side-effects were severe enough to stop therapy. $11.8 \%$ of patients reported severe abdominal pain and were found to have simple follicular cysts on transvaginal scan. This was comparable to the incidence of ovarian cysts seen in other studies, Rajan et $\mathrm{al}^{23}(15 \%)$ and Kriplani et al $(7.1 \%)$. These cysts are usually follicular and disappeared in subsequent cycles. $9.2 \%$ of the patients complained of vaginal discharge and were found to have cervical erosion on per-speculum examination and acute on chronic inflammation on Pap smear, which were treated accordingly. A few patients complained of gastric upset $(7.10 \%)$; vague abdominal pain $(6.2 \%)$, headache $(4.8 \%)$ and weight gain $(2.9 \%)$. Amenorrhea was noted in $8 \%$ of cases but majority of these women were perimenopausal and this was welcomed by them.

The nonsteroidal, once a week oral contraceptive, ormeloxifene is an unique need oriented contraceptive agent ${ }^{24}$ which was included in the National Family Welfare Program of India in 1991. Since then, it has been used by over 1,00,000 women and has shown an excel- lent therapeutic index and is considered safe for chronic administration.

Ormeloxifene normalizes the bleeding from the uterine cavity by regularizing the expression of estrogen receptors on the endometrium. It prevents proliferation of endometrium and does not affect the cornification of vaginal and cervical epithelium. Ormeloxifene competes with estradiol E2 for binding with cytosol receptors. It not only blocks the cytosol receptors but also causes their prolonged depletion and has long lasting post withdrawl effect. In therapeutic doses it does not effect the secretions of pituitary, thyroid or adrenal hormones. ${ }^{25}$

An ideal therapy for menorrhagia in perimenopausal women is one that, prevents bone loss, has positive effect on cardiovascular system and carries no risk of breast or uterine cancer. Ormeloxifene satisfies all the above mentioned conditions.

\section{CONCLUSION}

Ormeloxifene decreases mean blood loss significantly in the first two cycles itself. The effect does not plateau, rather further reduction is seen in the subsequent cycles. This reduction in menstrual blood loss is greater than that, achieved by other oral medication.

To facilitate the drugs steady state concentration in plasma a twice weekly loading dose in the beginning of therapy is to be considered for the first 3 months and then a step down to a weekly dosing schedule gives a better compliance and decreases the relapse cases.

Action of ormeloxifene is local and has no effect on the hypothalmopituitary axis so the drug has a good safety profile and can be safely used in pre and perimenopausal women on a long-term bases without any significant adverse effects.

It is a good drug for perimenopausal women especially in women in whom steroidal treatment is either not recommended or not desired. Ormeloxifene is an effective, safe and a well-tolerated option for the management of dysfunctional menorrhagia. 


\section{REFERENCES}

1. Hallberg L, Hodgahl AM, Nilsson L, et al. Menstrual blood loss-a population study. Acta Obstet Gynecol Scand 1966; 45:320-351.

2. Monteiro I, Bahamondes L, Diaz J. Therapeutic use of Levonorgestel releasing intrauterine system in women with menorrhagia. A pilot study. Contraception 2002;65:325-328.

3. Higham JM, O'Brien PM, Shaw RW. Assessment of menstrual blood loss using a pictoral chart. Br J Obstet Gynaecol 1990; 97:734-739.

4. Liu DTY. Treatment of dysfunctional uterine bleeding. Am enorrhea need not be the end point BMJ 1995;310:802.

5. Lethaby A, Hickey M, Garry R. Endometrial destruction techniques for heavy menstrual bleeding. Cochrane Database Syst Rev 2005;4:CD001501.

6. Munro MG. Medical management of abnormal uterine bleeding. Obstet Gynecol Clin North Am 2000;27:287-304.

7. Coulter A, Kelland J, Petro V, et al. Treating menorrhagia in primary care: an overview of drug trials and a survey of prescribing practice. Int J Tech Assess Health Care 1995;456-471.

8. Winsor SHM, Fisher S, Hahn PM, et al. Retrospective valuation of the long-term outcomes following conservative management of menorrhagia in ovulatory women. LSOC Obstet Gynecol Can 1999;2:155-163.

9. Milsom I. The Levonorgestrel-releasing intrauterine system as an alternative to hysterectomy in perimenopausal women contraception 2007;75:5152-5154.

10. Lal J, Asthana OP, et al. Optimization of contraceptive dosage regimen of centchromam. Contraception 2001;63:47-51.

11. Singh MM, Centchroman. A selective estrogen receptor modulator, as a contraceptive and for the management of hormone related clinical disorders. Med Res Rw 2001;21: 303-347.

12. Mishra NC, Nigam PK, Gupta R. Centchroman: a nonsteroidal anti cancer agent for advanced breast cancer phase II study. Int J Cancer 1989;43:781-783.
13. Sankaran MS, Prasad MRN. Mode of action of a new nonsteroidal postcoital antifertility agent (centchroman 67/20 CDRI) in rats, Contraception 1974;9:279-289.

14. Singh MM, Kamboj VP, Kar AB. Effect of intravaginal instillation of some nonsteroidal oral anti-infertility agent on pregnancy in rats. Ind J Exp Biol 1974;12:370-371.

15. Hallberg L, Nillsson L. Determination of menstrual blood loss. Scand J Clin Lab Invest 1964;16:244-248.

16. Farquhar CM. Management of dysfunctional uterine bleeding. Drugs 1992;44:578-584.

17. Lal J, Asthana OP, Nityanand S. Pharmacokinetics of centchroman in healthy female subjects after oral administration. Contraception 1995;52:297-300.

18. Bonnar J, Sheppard BL. Treatment of menorrhagia during menstruation. Randomized control trial of ethamsylate, Mefenamic acid and tranexamic acid. BMJ 1996;313:579-582.

19. Milsom I, Andersson K, Andersch B. A comparison of Flurbiprofen, tranexamic acid and a Levonorgestral releasing intrauterine contraceptive device in the treatment of idiopathic menorrhagia. Am J Obstet Gynecol 1991;164:879-883.

20. Kriplani A, Kulshrestha V, Agarwal N. Efficacy and safety of ormeloxifene in management of menorrhagia: a pilot study. J Obstet Gynecol Res 2009;35(4):746-752.

21. Chandra BS, KumarSS, Shanker BT, et al. Ormeloxifene a selective estrogen receptor modulator, for treatment of dysfunctional menorrhagia. J Obstet Gynecol Ind 2004;54(1):56-59.

22. Tapan KB, Anusyua B, et al. Efficacy of a selective estrogen receptor modulator 'ormeloxifene' in management of dysfunctional uterine bleeding. J South Asian Fed Obstet Gynec 2010;2(3):207-211.

23. Rajan R. Contraceptive and noncontraceptive benefits of centchroman. Asian J Obstet Gynecol Practice 1996;1:65-71.

24. Lal J. Clinical pharmacokinetics and interaction of centchroman a mini review. Contraception 2010;81(4):275-280.

25. Patel KP, Patel VJ. Selective estrogen receptor modulators (SERMS). OnlineJ Smt NHL Municipal Med Coll. Ahmedabad. Available at: www:nhlmmcgym.com/selective estrogen.htm. 